Dr. A.G.P. van der Wall

Department of Latin

\title{
EARLY MEDIEVAL STYLISTIC RHETORIC
}

According to the well-known expert on medieval rhetoric, James $\mathrm{J}$. Murphy, the three typical medieval forms of rhetoric are the art of letter writing, the art of preaching and the art of poetry (Murphy, $1971^{1}$, p. xv). In this paper we are conc erned only with the second of these arts, namely, the rhetoric of preaching. Though the preceptive treatises on the rhetoric of preaching, the so-called arles praedicandi, did not originate before the thirteenth century, pulpit rhetoric was very much alive in the earlier part of the Middle Ages and fine examples of this kind of eloquence can be quoted.

It would be an anachronism, however, to apply the standards of classical rhetoric to early medieval rhetoric, because only one element of classical rhetoric survived beyond the time of the Fathers (Kendall, 1978, p. 149). This greatly reduced kind of rhetoric is sometimes called 'stylistic' rhetoric in contrast with the full scope of classical or 'Ciceronian' rhetoric (Howell. 1961. p. 6), because it relies almost exclusively on figures of speech for the adornment of discourse (Croll, 1966, p. 264).

Augustine's work De doctrina christiana was mainly responsible for popularizing stylistic rhetoric in the field of preaching (Croll, 1966, p. 256). According to Augustine the aim of preaching is 'to teach, to delight, and to influence the will' (docere, delectare, flectere - De doct. chr., IV, 96), and he specifically mentions eloquence as one of the instruments to obtain this goal (De doct. chr., IV , 4-5). Furthermore, in the field of eloquence the figures of speech (tropi) are especially important since they are also used in the Bible (De doct. chr., III, 87-8). Augustine further expresses the opinion that eloquence should be acquired only at a youthful age (1)e doct. chr., IV, 6 and 8). and even then is not necessary to learn it from a rhetorician: it can be picked up merely by reading the works of ecclesiastical authors or by listening to and imitating eloquent speakers (De doct. chr., IV, 9, 12 and 22).

These views of Augustine exerted a profound influence on medieval preaching (Murphy, $197 \mathrm{I}^{2}$, p. xiii). Not the least among those who put Augustine's ideas into practice was the Anglo-Saxon monk and scholar, the Venerable Bede. Living roughly three centuries after Augustine, Bede wrote, among numerous ot her works, a short treat ise, De schematibus et tropis, on the stylistic devices of elocutio. In this little treatise he defines and illustrates thirty different figures of speech - seventeen schemata and 
thirteen tropi. As far as the definitions are concerned, Bede does little more than quoting the Ars Maior of Aelius Donatus, the famous grammarian of the fourth century and teacher of St Jerome. In one respect, however, Bede introduces an innovation in this booklet: the examples to illustrate the figures of speech are no longer drawn from the classical authors but, with one exception, come from the Latin translation of the Bible.

In the remaining part of this article an attempt will be made to illustrate from Bede's own preaching how he utilized his knowledge of the schemes and tropes to cast his message into an attractive form. In the process two facts will emerge: firstly, that Bede used in his homilies not only most of the schemes and tropes discussed in his treatise, but also a few which are not mentioned there; secondly, that Bede's use of stylistic devices is not simply an aimless playing with the sound and order of words, but that it invariably serves the purpose of strengthening a moral or dogmatical truth.

Anaphora, repetition of the same word at the beginning of successive sentences or clauses (Lanham, 1968, p. 8), is one of the most frequently used figures in Bede's homilies. In the exposition of Mark 1:7, 'After me comes one who is mightier than I', Bede gives an indication of the vast difference between John the Baptist and Christ by contrasting four times the words 'mighty' (fortis) and 'mightier' (fortior):

Fortis quidem est multum qui in confessionem peccatorum, fortior qui in remissionem baptizat;

fortis qui spiritum sanctum habere dignus est, fortior qui tribuere;

fortis cui inter natos mulierum maior nemo est, fortior cui minorato paulo minus ab angelis omnia subiecta sunt sub pedibus eius;

fortis qui regnum caelorum primus venit praedicare, fortior qui hoc solus potuit dare.

(Homily I, 1.120-7).

In the fourth couplet the effect of anaphora is further strengthened by means of rhyme and rhythm: planus rhythm in potuit dore and trispondaicus in venit praedicare (for the different kinds of stress rhythm, see Polheim, 1925, pp. 73-7: Croll, 1966, pp. 303 ff; Willis, 1964, pp. 113-17).

In the introductory part of Homily I, 9 Bede uses anaphora to draw the attention of his hearers to the three principal ideas developed in the homily: Commendat enim nobis beatissimus evangelista et apostolus Iohannes privilegium amoris praecipui quo ceteris amplius meruit honorari a domino; 
commendat testimonium evangelicae discriptionis quod veritate divina subnixum nullus fidelium dubitare permittitur;

commendat placidam suae carnis absolutionem quam domino specialiter se visitante percepit. (Homily I, 9.4-9).

Bede uses several variations of anaphora. In Homily I, 11 he uses one word (incircumcisi) no less than seven times in order to bring out the full meaning of spiritual circumcision (Homily I, 11.183-99). In this instance he selects a word from a Scriptural text (Acts 7:51) and repeats it seven times, each time attaching a new meaning to it. In his exposition of Luke 2:52, 'As Jesus grew up he advanced in wisdom and in favour with God and men' ( $E t$ lesus proficiebat sapientia et aptate et gratia apud Deum el homines), he wants to emphasize the fact the this advance of Jesus was according to his human nature. Instead of repeating the whole verse, he repeats his explanation three times: 'according to his human nature he advanced...' (Iuxta hominis naturam proficiebal), and each time adds a different word from the verse: sapientia ... aetate ... gratia. The whole passage therefore looks like this:

Iuxta hominis quippe naturam proficiebat sapientia non quidem ipse sapientior ex tempore existendo qui a prima conceptionis hora spiritu sapientiae plenus permanebat sed eandem qua plenus erat sapientiam ceteris ex tempore paulatim demonstrando.

Iuxta hominis naturam proficiebat aetate quia de infantia ad pueritiam de pueritia ad iuventutem consueto hominibus crescendi ordine pervenit.

Iuxta hominis naturam proficiebat gratia non ipse per accessum temporis accipiendo quod non habebat sed pandendo donum gratiae quod habebat.

(Homily 1, 19.181-90).

The words of John the Baptist in John 1:30, Post me venit vir qui ante me jactus est quia prior me eral, are explained in a very neat way. The whole sentence is repeated and explained three times; while the explanation remains basically the same, Bede each time uses fewer words until his third explanation culminates in three rhyming words:

Post me venit vir qui ante me factus est quia prior me erat:

post me venit humanitale,

qui ideo me praecellit dignitate,

quia prior me erat divinitate.

(Homily I, 15.48-51).

Although Campbell describes the language of Homily 1,7 as 'simple to the point of austerity' (Campbell, 1978, p. 184), this homily contains one of the finest and most elaborate examples of anaphora. Bede's exposition of Luke 
2:19, 'But Mary treasured up all these things and pondered over them', revolves around six quotations from Old Testament prophecies which are grouped in three pairs. Each quotation is introduced by the word legerat. The first and second pair of quotations are preceded and followed by sentences beginning with the verb videbat. The word videbat is substituted by meminerat in the sentence preceding the third pair of quotations, and by audiebat in the sentence following the third pair. Thus the initial words of the twelve consecutive sentences form this pattern:

videbat ... legerat ... legerat ... videbat;

videbat ... legerat ... legerat ... videbat;

meminerat ... legerat ... legerat ... audiebat.

(Homily I. 7.125-49).

These few examples of anaphora in Bede's preaching (and there are many more) clearly illustrate that Bede tried his best to make his exposition as easy as possible for his audience. Even the simplest monk could not fail to catch at least one of the iterated explanations. Baldwin's view of the force of refrain seems therefore to be fully justified: 'The very insistence exhibits strikingly the value of cumulative progress for charging exposition with emotion' (Baldwin, 1928. p. 256).

Homoioteleuton. like endings of phrases or sentences (Lanham, 1968, p. 54), occurs, like ana phora, almost in all Bede's homilies. As this scheme is used so often, it is impossible to discuss all the examples that I have found. Nevertheless, a few selected examples will be sufficient to illustrate Bede's predilection for this scheme.

That homoioteleuton in Bede's homilies is not always and not merely the result of the inherent characteristics of Latin, but intentionally contrived, is illustrated in Homily. I, 6 where he quotes Romans 13:12 but adds a few: words of his own to produce a rhyming pattern (the added words are italicized):

1 nox praecessit antiquae caecitatis

2 dies autem adpropinquavit aeternae salutis

3 et ipsi abiciamus opera tenebrarum

4 et ut filii lucis ambulemus

(Homil) 1.6.259-61,.

The pattern of homoioteleuton in members 1 and 2 is obvious: -it ... -ae ... -t is. Less obvious is the occurrence of rhythm or cursus in all four members: trispondaicus. planus, velox and trispondaicus. The parallelism between members $l$ and 3 . and between 2 and 4 (nox - tenebrae; dies - lux) and the anapohora acquired in members 3 and 4 should also be noted. 
A sentence occurs in Homily I,25 in which three pairs of consecutive verbs in the imperfect subjunctive produce homoioteleuton in the last and penultimate words of each member:

l Sed absit ut terrena stultitia quid diceret inveniret,

2 et caelestis sapientiae quid responderet deficeret;

3 absit ut impietas caeca soli iustitiae ne mundo luceret obsisteret (Homily I,25.50-3).

The following sentence from Homily II, 8 which describes the human nature of Christ, uses homoioteleuton to great effect; the sharp contrast between the rhyming words should especially be noted:

l Non enim haec de coaet erna patri divinitate

2 sed de adsumpta loquitur humanitate

3 quam suscipiendo minoratus est

4 paulo minus ab angelis

5 et in qua resurgendo a mortuis

6 gloria et honore coronatus est (Homily II,8.54-7).

The contrast between the rhyming words in the introductory sentence of Homily II.16 is again striking:

1 minus capaces erant ad intellegenda archana divinae sublimitatis

2 minus fortes ad toleranda adversa humanae pravitatis

3 sed eis adveniente spiritu cum augmento divinae agnitionis

4 data est etiam constantia vincendae humanae persecutiionis (Homily II, 16.2-6).

In the following sentence from Homily II,22 the dual nature of love is expressed not only through rhyme, but also through rhythm:

l Haec sola et vera est probatio integri in Deum amoris (planus)

2 si erga fratres studueris curam solliciti exercere laboris (planus) (Homily II,22, 10-11).

The transformation which is effected through baptism, is described in a striking passage in Homily II, 18:

I Sola autem fidelium pietas novit,

2 quia peccator in fontem descendit sed purificatus ascendit,

3 filius mortis descendit sed filius resurrectionis ascendit,

4 filius praevaricationis descendit sed filius reconciliationis ascendit,

5 filius irae descendit sed filius misericordiae ascendit,

6 filius diaboli descendit sed filius Dei ascendit.

7 Sola haec ecclesia mater quae generat novit (Homil) II, 18.62-8). 
Apart from the homoioteleuton of the final words of each member, a pattern of internal homoioteleuton may be observed in members 3 to $6:$-is ... -is; -onis ... -onis; -ae ... -ae; and -i ... -i. Furthermore, the homoioteleuton is coupled with planus rhythm in each member except in 5 , where trispondaicus is used.

A pattern of artificial word order of which Bede is very fond, but which is not discussed in his De schematibus et tropis, is chiasmus. Lanhan defines this scheme as follows: 'The term is derived from the Greek letter $\mathrm{X}$ (chi) whose shape, if the two halves of the construction are rendered in separate verses, it resembles' (Lanham, 1968, p. 22).

The utter contrast between Satan and Christ is described in the following way:

Ipse enim recte mors et mendacium sicut e contra dominus veritas vocatur et vita (Homily II,20.197-9).

Notable in this instance is the alliteraton of $m$-sounds to describe the character of the devil, and the alliteration of $v$-sounds which apply to the Lord. The polarization of mors-vita and mendacium-veritas is absolute. The teaching of John the Baptist concerning the two natures of Christ is expressed in a rhyming chiastic clause:

celsitudinem humanitatis eius pariter et divinitatis aeternitatem manifesta voce pronuntiat (Homily I,2.2-3).

Chiasmus is again used to describe the implications of Christ's incarnation: non solum homo fieri cum Deus esset sed etiam cum dives esset pauper fieri dignatus est. (Homily I, 18.48-50).

The contrast between Deus dives and homo pauper is thus neatly expressed. It is also possible to see a pun in Deus and dives.

To impress on the mind of his hearers the truth that any obedience and love displayed by the Christian is a sign of the Lord's grace rather than of the believer's devotion, Bede again uses this scheme:

non humani meriti sed

muneris esse divini

(Homily 1I,22.30-1). 
Cognate words, producing chiastic alliteration, are used to underline Christ's divinity and truth:

omnia divinae veritatis et

verae divinitatis ... archana

(Homily I,9.245-6).

Crosswise alliteration is again used in Homily II, 1 to describe the Christian's duty towards a fellow believer who lives a life of sin:

castigare polluta

perversa corrigere

(Homily II, 1.159).

Antonomasia, or the substitution of a descriptive phrase for a proper name Lanham, 1968, p. 12), is combined with chiasmus to describe Christ as cognitor meritorium ac sedium distributor (Homily II,21.64).

Sometimes the chiasmus is doubled, as in the following phrase which is reminiscent of a passage in the Benedictine Rule:

esurienti cibum

potum sitienti

algenti vestitum ministrando

(Homily I,9.157-8).

So, too, where some aspects of Christ's earthly ministry are described:

languentes curare

erudire nescios

contumaces redarguere

(Homily I,21.174).

Palindromic phrases come very close to chiasmus. A good example occurs in Homily I,9.237-8:

instructus revelatione ac sancti spiritus gratia debriatus.

In Homily II,6.90-1 it is combined with alliteration to describe the Christian's duty to avoid lies:

non loqui iniquitatem labiis nec lingua mendacium meditari.

While Bede's use of chiasmus and palindrome seems to be deliberate, it is almost impossible to say whether this is true of his employment of paroemion or alliteration, since the latter occurs naturally in language (Kendall, 1978, p. 159). In a few instances, however, it is used in such an elaborate way 
that it is hard to think of it as accidental. Thus alliteration is combined with homoioptoton (according to Lanham, 1968, p. 54, 'the use of various words in a sentence or verse with similar case endings') to describe Christ's gentleness: mansuetum mitemque ac misericordiae supernae praeconem ministrumque

(Homily I, 12.121-2).

In addition, the word endings in this phrase form a palindromic pattern: -um, -em, -ae, -ae, -em, -um.

When he discusses the kingship of Christ, Bede again uses alliteration in a very striking way:

iuravit Dominus David de fructu ventris eius sedere super sedem suam sed...

(Homity II.24.47-9).

Not only is a series of three consecutive words in d-followed by a series of five consecut ive words in s-, but the initial syllables of the s-words also form a palindromic pattern: sed-, su-, sed-, su-, sed.

Paronomasia or punning appears to be a more deliberately used figure Huppé, 1959. p. 40). Though Bede does not use it as often as some of the other figures, it still occurs a number of times. In a sentence which describes the inability of Old Testament law to lead men to a life of perfection, a pun between edoctos and eductos appears:

Legis siquidem littera quae nescientes quid agendum quid vitandum esset edocuit nec tamen edoctos ut sua decreta conplerentur adiuvit quasieductos de sedibus ignorantiae prioris in porticibus suis continebat nec sanabat languidos

(Homily 1.23.41-5).

To accentuate the truth that prayer should be complemented by moral behaviour, a pun is made of oratio and operatio:

Sic etenim subplicantes concite quae desideramus accipimus quia nimirum verba devotae orationis adiuvat manus piae operationis (Homily 11.20. 213-15).

A pun is made of ore and opere to press home the point that the true praise of God should consist of both words and deeds:

Sic enim solummodo Deo nostro iucunda fit laudatio, si quod ore canimus non inpugnamus opere...

(Homily II.16.381-2). 
Paronomasia is again used to intensify the consolation that the toils of this life are comparatively brief and light:

Breve nimirum videtur et leve totum quicquid aeterna beatitudine finitur (Homily II,24.339-41).

A scheme which Bede incorrectly classed among the tropes, but one of which he was extremely fond, is hyperbaton. This scheme of artificial word order is, according to Kendall, 'the one which more than any other, gives Bede's prose its distinctive flavor' (Kendall, 1978, p. 153). Hyperbaton is briefly described by Lanham as 'the separation of words usually belonging together' (Lanham, 1968. p. 56). Not to go into all the many intricacies of hyperbaton we may sirr slify matters by looking only at two types of separation, namely the separation of an adjective and a noun, and the separation of a preposition from its object.

The simples kind of hyperbaton may be seen in the following phrases:

in veram caelest is vitae beatitudinem (Hom. I,2.132);

unica animae nostrae salus (Hom. II,24.78-9);

ad caelestis regni gaudia (Hom. II, 14.1);

per cordis sui munditiam (Hom. II, 19.219).

A more complex form of hyperbaton is formed when two simple hyperbata interlock, as in the following examples:

visa suorum putredo vulnerum (Hom. II, 14.46);

praedicanda sui dona redemptoris (Hom. II,20.139-40);

per divinae unitatem potentiae (Hom. Il,21.165-6);

pro mei confessione nominis (Hom. I,9.36);

ad aeterna caelestium tendit praemia gaudiorum (Hom. II,13.132).

In this last instance both hyperbata are also interrupted by the verb tendit.

Bede's use of cursus has already been mentioned. Though he did not invent these rhythmical clause endings, he was the first to give recognition to stress rhythm as a literary form by including a paragraph on this topic in his De arte metrica. As far as the early Middle Ages are concerned, usually four rhỵthmical patterns are distinguished: cursus planus (' - ' -), cursus trispondaicus (' ...'-), cursus tardus (' - - - ) and cursus velox (' - . - . or sometimes '..' - - ). These cadences were already present in the Gregorian Sacramentary (Willis, 1964, p. 113) which was used in Bede's monastery, and it was only natural that Bede utilised them in his homilies to give 'a beautiful flow at the end of a rhetorical unit' (Croll, 1966, p. 306), in order to make his preaching more attractive and effective. 
A rhetorical figure which possesses some charm and is occasionally used by Bede (though not mentioned in his De schematibus et tropis), is isocolon or 'the repetition of phrases of equal length and usually of corresponding structure' (Lanham, 1968, p. 62). As a rule these phrases have like endings and often contain cursus. A fine example of isocolon conveys the basic gospel message of Christ's death:

Ipse suum pro nobis sanguinem fudit, suam pro vita nostra mortem obtulit (Homily II, 14.51-2).

Both members consist of twelve syllables and end in planus rhythm. A similar example gives expression to the idea that eternal glory is won through struggles:

Promisit nobis dona gloriae

sed praemisit certamina pugnae.

(Homily II,21.8).

Each member consists of ten syllables, though only the second has cursus. The pun between promisit and praemisit further intensifies the contrast between dona and certamina.

There are also a number of schemes which appear less frequently in Bede's homilies. Scesis onomaton (several synonyms used consecutively - Lanham, 1968, p. 90) can be seen in Homily II,7:

Et bene in Galilaea videtur a discipulis qui iam de morte ad vitam, de corruptione ad incorruptionem, de poena transmigraverat ad gloriam (Homily II, 7. 160-3).

Hypozeuxis (a separate verb used for each clausula - Lanham, 1968, p. 58) and asyndeton (the omission of conjunctions - Lanham, 1968, p. 18) are combined in Homily II, 11 :

Sed quia sunt nonnulli qui spiritus gratia pleni infirmos curant mortuos suscitant daemonibus imperant multis virtutibus coruscant ipsi angelicam in terris vitam gerunt ...

(Homily II,11.154-7).

Examples of polysyndeton (the use of many conjunctions - Lanham, 1968, p. 78 ), anadiplosis (the same word used to end one sentence or clause and to begin the next - Lanham, 1968, p. 7), epanalepsis (the same word used to begin and end a sentence or clause - Lanham, 1968, p. 42) and epizeuxis (the same word used consecutively in the same sentence - Lanham, 1968, p. 46) can be given, but as these schemes are of no great importance in Bede's prose, they can be left aside. Polyptoton (the same word or stem used several 
times but in different cases - Lanham, 1968, p. 78) seems to be of slightly greater importance:

Lnde merito illum scire omnia quasi Deum et quasi Dei filium a Deo venisse credunt et confitentur (Homil, 11.12.184-6).

Syllepsis (defiance of rules of concord - Lanham, 1968, p. 95) seems to be more interesting than important, and not a scheme widely used by Bede. Only the following example, where una is used in a plural sense, has been noted:

una eademque sunt dona virtut is

(Homil) II.12.157 8).

Bede also uses several of the tropes mentioned in his De schematibus et tropis. Attention has already been drawn to examples of antonomasia and hy pterbaton. Allegory appears on almost every page of Bede's homilies. The reason for this must be sought in the fact that since the time of Origen Christian exegetes believed that the Bible possessed different levels of meaning. Apart from the literal sense of the Bible, there were also three tigurative senses, one of which was the allegorical. As Bede's exegesis deserves an article of its own, only a few examples of his allegorical exegesis will be given. In Homily I, 22 Bede gives the daughter of the Canaanite woman this allegorical meaning:

Filia daemoniosa pro qua postulat anima quaelibet est in ecclesia malignorum magis spirituum deceptionibus quam conditoris sui mancipata praeceptis...)

Homil, I. 22.90-2).

Homiiy I.14, which deals with the miracle performed by Jesus at the wedding in Cana. abounds in figurative interpretation. The six stone water-jars which were used by Jesus to turn water into wine, are seen to represent outstanding figures from each of the six ages of this world:

Aqua autem scripturae sacrae scientiam designat quae suos auditores et a peccatorum sorde abluere et divinae cognitionis solet fonte potare: vasa sex quibus continebatur corda sunt devota sanctorum quorum perfectio vitae et fidei exemplum recte credendi ac vivendi proposita est generi humano per sex saeculi labentis aetates, id est usque ad tempus dominicae praedicationis

Homily I.14.98-104).

David. for instance, serves as the example from the fourth age; because he suffered persecution at the hands of Saul, he allegorically typifies Jesus who was persecuted by the Jew's: 
At si in Saule Iudaeos persequentes in David Christum et ecclesiam significari cognoverit...

(Homily I, 14.188-90).

An example of metaphor, which is defined by Lanham as 'changing a word from its literal meaning to one not properly applicable but analogous to it' (Lanham, 1968, p. 66), can for instance be seen in Homily II, 12.211 where Bede speaks of the 'eyes of the heart' (oculi cordis).

Metonymy, the changing of a name (Lanham, 1968, p. 67), can be seen in the following sentence:

Mundum autem appellat homines mundi huius amori deditos sicut $\mathrm{e}$ contra sancti qui caelestium desiderio flagrant caeli recte vocantur (Homily II, 17-58-61).

Onomalopoeia, the 'use or invention of words that sound like their meaning' (Lanham, 1968, p. 69), is used a few times. Thus in Homily I, 25 Bede describes how the Pharisees listened to Jesus:

Audierunt invidi et dissoluti sunt nec conpuncti sunt temptaverunt eum et deriserunt derisu striderunt in eum dentibus suis (Homily I, 25.42-4).

The circumstances under which Moses received the Law on Mount Sinai are described in the following way:

Ibi inter flammas ignium et micantia fulgura fragor quoque tonitruorum et clangor sonabat bucinae...

(Homily H, 17.237-9).

There are also in Bede's homilies a few examples of homoeosis or simile (Lanham, 1968, p. 54). Explaining why and how Jesus took food after his resurrection, Bede says:

Simpliciter itaque et pie sentiendum est resuscitatum a morte et inmortale iam factum corpus dominicum nullam quidem necessitatem at tamen facultatem habuisse vescendi, ideoque ubi oportunitas probandae substantiae naturalis exigebat cibis esse refectum, qui nimirum cibi nullum saginae adiumentum ut mortalium corporibus solent illi praebuerint, sed quomodo in ignem missa aqua ita mox comest $i$ spiritali eius sint virtute absumpti

(Homily 11,9.171-8).

Evil thoughts which keep on returning to the mind are likened to a swarm of flies which keep on circling around one's head (Homily, Il,12.210-12). 
Bede often makes the schematic ornament more obvious (and also more effective) by weaving several different schemes together in a complicated pattern. Thus no less than ten different schemes and tropes are clustered together in a single sentence in Homily II,7 in order to accentuate the glorious victory of Christ over Satan:

1 Agnus qui tollit peccata mundi leonem qui intulit peccata mundo confregit,

2 agnus qui nos suae carnis et sanguinis libamine ne pereamus reficit,

3 leonem qui nos rugiens circuivit et quem de nobis perdat inquirit,

4 agnus qui suae mortis signum frontibus nostris ad discutienda tela mortiferi hostis inposuit

(Homily II, 7.206-11).

In this passage the following figures are used:

(i) Homoioteleuton on -it in the final words of each member, and a transverse pattern of word-endings in member $1:-i t,-t a,-i t,-t a,-i t$.

(ii) Cursus: planus in members 1 to 3 , tardus in 4 .

(iii) Near isocolon in members I to 3: 25, 24 and 22 syllables respectively.

(iv) Anaphora in memb 3 rs 1,2 and 4 (agnus qui), alternated with leonem qui in members 1 and 3 .

(v) Polyptoton of several words: mundi - mundo; qui - quem; nos - nobis.

(vi) A repeated pattern of paroemion in member 1 : qui .. pec-... mun-.

(vii) Zeugma: all the relative clauses depend on the verb confregit.

(viii) Onomatopoeia: leo rugiens.

(ix) Metonymy: agnus and leo used for Christ and Satan.

(x) The word tela is used metaphorically.

The examples of Bedes's rhetoric which we have quoted make it clear that Bede tried his best to present the content of his preaching in a attractive guise. The majority of modern scholars are agreed on the eloquence, clarity and simplicity with which Bede delivered his homilies. But already in the Middle Ages Bede was known for his eloquence. Writing to Gisla, the sister of Charlemagne, in A.D. 801, Alcuin coined the phrase sermo simplex as the standard medieval description of Bede's style (Alcuin, Ep. 216). William of Malmesbury, too, appreciated the sweetness of Bede's eloquence when he said of him, 'dulcis fuit eloquentiae' (William, Gesta Regum Anglorum, I,59). Having learned Latin in his boyhood as a completely foreign language (Blair, 1970, p. 244), Bede eventually used it with great competence as a useful tool in his exegesis and preaching (Riché, 1976, p. 381). One can only speculate about the source of Bede's eloquence. Two possibilities seem to present themselves. The first is that Bede acquired his proficiency in Latin largely through his own efforts, by studying the existing textbooks and by reading the works of eloquent authors such as Ambrose, Jerome and 
Augustine. If this is indeed the secret behind Bede's knowledge of Latin, it proves the truth of Augustine's dictum, mentioned before, that eloquence can be learned without the intervention of a rhetorician merely by imitating eloquent men: 'Nec desunt ecclesiasticae litterae ... quas legendo homo capax ... etiam eloquio quo dicuntur, dum in his versatur, imbuitur' (Augustine, De doct. chr., IV,9). The only other solution is that Bede must have had a competent teacher who taught him how to appreciate and write good Latin, in which case some at least of his hearers might have shared the same knowledge of Latin prose style.

\section{REFERENCES}

ALCL'IN. Epistolae. Ed. by E. Dümmler. 1895. Monumenta Germaniae Historica, Epistolae IV'. Berlin

AUGUSTINE. De doctrina christiana. Printed in Corpus Scriptorum Ecclesiasticorum Latinorum, vol. LXXX. Vienna.

BALDWIN, C.S. 1928. Medieval Rhetoric and Poetic, to 1400). New York.

BEDE. De arte metrica. Printed in Corpur Christianorum S.L. vol. CXXIII A.

BEDE. De schematibus et tropis. Printed in Corpus Christionorum S.L. CXXIII A. Tumhout.

BEDE. Homeliarum Evangelii Libri II. Printed in Corpus Christianorum S.L. CXXII. Turnhout. BLAIR. P.H. 1970. The World of Bede. London.

C.AMPBEL.L. J.J. 1978. 'Adaptation of Classical Rhetoric in Old English Literature'. In: Medieval Eloquence. Studies in the Theory and Practice of Mediei al Rhetoric. Ed. James J. Murphy. Berkeley:

CROLL, M.W: 1966. Style, Rhetoric, and Rhythm. Ed. by J. Max Patrick and others. Princeton.

HOWELL, W.S. 1961. Logic and Rhetoric in England, 1500-1700. New York.

HL PPÉ. B.F. 1159. Doctrine and Poetry, Augustine's Inlluence on Old English Poetry. New lork.

KEXMI.L. C.B. 1978. Bede's Historia Ecclesiastica: the Rhetoric of Faith'. In: Medieval Eloquence. Studies in the Theory and Practice of Medieval Rheronc. Ed. by James J. Murphy. Berkeley. 1.A.HAM. R.A. 968. A Handist of Rhetorical Terms. Berkeley.

MLRPHI. J.J. 1971'. Threc Medieval Rhetorical Arts. Berkeley.

ML'RPHY. J.J. 1971². Medieval Khetoric. A Select Bibliography. Toronto.

POLHEIM. K. 1925. Dic lateinische Reimprosa. Berlin.

RICHÉ. P. 1976. Education and Culture in the Barbaraian W'est. Sixth Through Eighth Centuries. Tr. from 3rd French ed. by John J. Contreni. Columbia.

TANENHALS. Gussic Hecht. 1962. 'Bede's De schematibus el tropir - a translation.' In: The Quarterly Journal of Speech, 48:237-53. Illinois.

WETHERBEE. W. 1978. 'Some implications of Bede's Latin style.' In: Bede and Anglo-Saxon England. Ed. by R.'T. Farrell. British Archeological Reports 46. Oxford.

WIILIAM OF MAIAMESBLRY'. Gesta Regum Anglorum. Ed. by W. Stubbs. 1887.Rolls Silles. London.

WIL.L.IS. G.(;. 1964. Lssays in Early Roman Liturg!. London. 